Огляди літератури, оригінальні дослідження, погляд на проблему

УДК 616.71/72-018.3-007.248-092-06:[616.37-02++616-036]

DOI 10.11603/1811-2471.2017.v0.i2.7725

\title{
КЛІНІКО-ПАТОГЕНЕТИЧНІ АСПЕКТИ ОСТЕОДЕФІЦИТУ ПРИ ОСТЕОАРТРОЗІ У ПОЄДНАННІ 3 ХРОНІЧНИМ ПАНКРЕАТИТОМ
}

\author{
๑Л. С. Бабінець, Т. Г. Маєвська
}

ДВНЗ «Тернопільський державний медичний університет імені І. Я. Горбачевського МОз України»

РЕЗЮМЕ.У статті розглянуті сучасніпоглядинапроблемукоморбідностіостеоартрозу,хронічногопанкреатиту і остеодефіциту. Проаналізовані дані двофотонної рентгенівської денситометрії, а також показники рівня активації перекисного окиснення ліпідів, антиоксидантної системи захисту і деструкції тканини. Продемонстровані дані кореляційно-регресійного аналізу між наведеними вище показниками і основними характеристиками хронічного панкреатиту та остеодефіциту у хворих аналізованого контингенту.

Матеріали та методи. Проведено комплексне обстеження 72 хворих. Пацієнтів поділено на дві групи: 30 хворих на ОА та 42 - на ОА у поєднанні з ХП. Контрольна група складалася з 20 практично здорових осіб. Оцінку КТ проводили за допомогою двофотонного рентгенівського денситометра (Dual Energy X-Ray Absorptiometry - DXA) фірми Lunar corp. (Madison, WI) - Lunar DPX-A № 2589 в поперековому відділі хребта. Аналіз показників проводили згідно з рекомендаціями Всесвітньої Організації охорони здоров'я (WHO, Geneva, 1994) [19]. Дослідження показників ПОЛ проводили за рівнем малонового альдегіду (МА). Для оцінки АОЗ визначали СОД, церулоплазмін (ЦП), SH-групи, каталазу. Ендогенну інтоксикацію і рівень деградації сполучної тканини в організмі оцінювали за рівнем вільного оксипроліну. Вплив наявності ХП на стан ПОЛ-АОЗ встановлювали за наступними основними клінічними характеристиками ХП: вік пацієнтів, структурний стан ПЗ за методом УзД, виражений у балах. Екскреторну функцію ПЗ досліджували за допомогою визначення фекальної а-еластази методом імуноферментного аналізу за допомогою стандартних наборів фірми BIOSERV ELASTASE 1-ELISA.

Результати. При обстеженні мінеральної щільності кісткової тканини за допомогою двофотонного рентгенівського денситометра було з'ясовано, що наявність у хворих на ОА супутнього ХП призвела до суттєвого зниження МЩКТ і погіршення стану КТ: знизилась частка хворих з нормальною кісткою з 67 \% до 16 \%, збільшиласьзостеопенієюз 10\% до 67\%, з'явились Хворі з ОП-17\%. Окрім посилення деградаціїКТ при ОАна тліХПпосилювалися показники оксидативних змін (рівень МА) і знижувалися показники АОЗ (рівень СОД і SН-груп), характерне було збільшення гостроти запалення та ендотоксикозу (рівень каталази, церулоплазміну), а також посилення деградації сполучної і кісткової тканин у суглобах і прогресування фіброзу у тканині Пз (рівень оксипроліну).

Висновки. Встановлено, що у хворих на ОА із супутнім ХП спостерігалося суттєве зниження МщКТ і погіршення стану КТ. Виявлено, що при поєднаному перебігу ОА+ХП з остеопенією спостерігається зниження АОЗ за рівнем СОД і SH-груп і достовірно високий рівень активації ПОЛ за даними МА, а також наявність деструктивних змін у сполучній і кістковій тканині і посилення остеопенії, на що вказує зростання оксипроліну.

КЛЮчОВІ СЛОВА: остеоартроз; остеопенія; остеопороз; хронічний панкреатит; антиоксидантний захист; перекисне окиснення ліпідів; оксипролін.

Вступ. Патологія кістково-м'язового апарату створює низку важливих і складних медичних проблем, впливаючи на економічний стан суспільства, здоров'я і якість життя пацієнтів та їх сімей. Однією $з$ таких проблем і найпоширенішим захворюванням суглобів, яке діагностується у $20 \%$ населення планети, є остеоартроз (ОА). В Україні офіційно зареєстровано більше 500 тис. хворих на ОА. За статистичними даними, зараз кожен третій мешканець страждає на ОА певних суглобів $[3,5,16]$. Поширеність ОА в популяції (6,3 \%) корелює з віком і досягає максимальних параметрів (13,9 \%) в осіб віком понад 45 років [4, 9]. ОА - це поліетіологічне захворювання, в основі якого лежить ураження всіх компонентів суглоба, насамперед хряща і субхондральної кістки $[14,17]$. Патогенез ОА складається з низки взаємопов'язаних ланок, внаслідок взаємовпливу яких формуються дегенеративно-деструктивні процеси у хрящовій і кістковій тканинах. Окрім того, в останні роки були проведені дослідження щодо високої частоти у хворих на ОА ураження внутрішніх органів, у тому числі й ураження шлунково-кишкового тракту. За даними Л. Б. Лазебника і В. Н. Дроздова [8], поєднання маніфестного ОА і захворювань ШКТ $€$ достатньо частим. Було також встановлено, що у пацієнтів з вказаним поєднанням патології реєструвалось понад 5 хвороб на кожного обстеженого, що дозволило авторам формувати проблему поліморбідності при ОА $[8,17]$. При захворюванні ШКТ, зокрема, при прогресуванні хронічного панкреатиту (ХП) як тривалого запального захворювання підшлункової залози (ПЗ), що ускладнюється фіброзом, кальцифікацією, екзокринною та ендокринною недостатністю, частим $€$ формування остеодефіциту (ОД) $[2,12,20]$. При ХП порушуються всмоктування та обмін вітаміну D і його метаболітів, а також виникає мальабсорбція кальцію та інших мінералів. Тому хворі на ХП складають групу ризику щодо виникнення або поглиблення порушень у кістковій тканині (КТ). При цьому при ХП, як і при ОА, відбувається активація перекисного окиснення ліпідів (ПОЛ) і зниження антиоксидантного захисту (АОЗ), розвивається ендо- 
Огляди літератури, оригінальні дослідження, погляд на проблему

генна інтоксикація, що також призводить до змін КТ у вигляді їі збільшення (остеосклерозу) або зменшення (остеопенії та остеопорозу (ОП)) [11].

Зниження мінеральної щільності кісткової тканини (МЩКТ) та їі демінералізація є основною причиною інвалідності у людей похилого віку. Розвиток остеодефіцитних станів (ОП і остеопенії) роками перебігає безсимптомно. Денситометрія як основний із методів ранньої діагностики дозволяє виявити схильність до захворювання та його глибину і своєчасно застосувати комплекс лікувальнопрофілактичних заходів для уникнення тяжких наслідків. ОА, остеопенія та ОП - надзвичайно важливі за своїм медико-соціальним значенням захворювання опорно-рухового апарату, які були відібрані серед п'яти найактуальних при проведенні Всесвітньої декади захворювань кісток і суглобів (The Bone and Joint Decade - 2000-2010). Збільшення частоти кожного з них асоціюється 3 віком, при порушенні функції ШКТ та його захворюваннях, зокрема, при ХП. При цьому вони мають свої особливості і безперервно зростають, що робить вивчення проблеми коморбідного перебігу ОА, ХП і ОД актуальним [1, 7, 13].

Мета - проаналізувати стан мінеральної щільності кісткової тканини, а також взаємозв'язки остеодефіциту і клінічних характеристик хронічного панкреатиту і параметрів ПОЛ-АОЗ у хворих на остеоартроз у поєднанні з хронічним панкреатитом.

Матеріал і методи дослідження. Було обстежено 72 хворих на ОА, які лікувались у денному стаціонарі Тернопільської міської комунальної лікарні № 2. Пацієнтів поділили на дві групи: 30 хворих - з ОА та 42 - з ОА у поєднанні з ХП. Серед проаналізованих хворих було 47 жінок (65 \%) і 25 чоловіків (35\%). Середній вік хворих становив $(57,3 \pm 5,1)$ років. Контрольну групу склали 20 практично здорових осіб. Діагноз ОА встановлювали 3 використанням уніфікованих діагностичних критеріїв $[10,14]$, рентгенологічну стадію ОА - за J. H. Kellgren i J. S. Lawrence. У дослідження включали пацієнтів з ураженням кульшового і колінного суглобів без синовіту з рентгенологічною стадією I-III і ПФС - I-II. Діагноз ХП верифікували згідно із загальноприйнятими в клініці критеріями [14]. У дослідження включили пацієнтів у фазі ремісії без цукрового діабету. Оцінку КТ проводили за допомогою двофотонного рентгенівського денситометра (Dual Energy X-Ray Absorptiometry - DXA) фірми Lunar corp. (Madison, WI) - Lunar DPX-A № 2589 в поперековому відділі хребта. Аналізували наступні параметри: МЩКТ поперекового відділу L1-L4 3 міжхребцевими щілинами, що враховує також і ос-

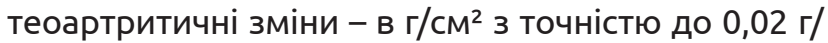
$\mathrm{CM}^{2}$; відносні показники - Т (peak bone mass) МщКТ стосовно здорових молодих людей 20-45 років в одиницях SD (standart deviations) - одиницях стандартних відхилень і показник Т в \% від рівня МЩКТ здорових молодих людей [7]. За Т-співвідношенням визначали ступінь щільності КТ (остеопенія, ОП чи остеосклероз). Оцінку показників проводили згідно із рекомендаціями ВОО3 (WHO, Geneva, 1994) [19]: Т вище (+1) -остеосклероз; Т в межах (-1)-(+1) - нормальний стан КТ; $(-1)-(-2,5)$ - остеопенія; Т нижче $(-2,5)$ - остеопороз.

Дослідження показників ПОЛ проводили за рівнем малонового альдегіду (МА) (визначали за реакцією Орхевич В. М. з тіобарбітуровою кислотою). Для оцінки АОЗ визначали СОД (за їі здатністю конкурувати з нітротетразолієм синім за супероксидні аніони); церулоплазмін (ЦП) (у сироватці крові за Ровіним); SН-групи (методом Бойєра 3 n-меркурбензоатом Na); каталазу (за рівнем розщеплення гідрогену пероксиду і визначенням співвідношення каталазного числа до кількості еритроцитів в 1 мл крові). Ендогенну інтоксикацію і рівень деградації сполучної тканини в організмі оцінювали за рівнем вільного оксипроліну (за методом Stegtmann у модифікації Осадчук М. А., Кузнєцової Т. П. і співавт.). Вплив ХП на стан ПОЛ-АОЗ встановлювали за наступними клінічними характеристиками ХП: вік пацієнтів, структурний стан ПЗ за методом УЗД, виражений у балах. Екскреторну функцію ПЗ досліджували за рівнем фекальної а-еластази (за методом імуноферментного аналізу наборами Bioserv Elastase 1-Elisa).

Результати обробляли статистично за допомогою ПК стандартними пакетами програм Microsoft Excel та Statistica for Windows версіï 6.0 (Stat Soft inc., США) і оцінювали за критерієм Стьюдента. Оцінку взаємозв'язків проводили за коефіцієнтами множинної кореляції R згідно із загальноприйнятими в статистиці критеріями: $\mathrm{R}<0,3$ - слабкий зв'язок; $\mathrm{R}=0,3-0,5$ - помірний; $\mathrm{R}>0,5-0,7$ - значний; R>0,7-0,9 - сильний; R>0,9 - дуже сильний, близький до функціонального зв'язку.

Результати й обговорення. При оцінці МЩКТ хворих на ОА I групи було виявлено 67,0 \% пацієнтів із нормальною МЩКТ, 23,0 \% - із остеосклерозом, 10,0 \% - із остеопенією (рис. 1).

При дослідженні II групи (ОА+ХП) стан кістки хворих оцінили наступним чином: у $67 \%$ - остеопенія, у $17 \%$ - ОП і у 16\% - нормальна МЩКТ (рис. 2). Таким чином було встановлено, що наявність у хворих на ОА супутнього ХП призвела до суттєвого зниження МЩКТ і погіршення стану КТ: знизилась частка хворих з нормальною кісткою 3 $67 \%$ до $16 \%$, збільшилась - з остеопенією з $10 \%$ до $67 \%$, з'явились хворі з ОП - $17 \%$.

У таблиці 1 наведено дані параметрів ПОЛАОЗ у групах порівняння хворих на ОА залежно від наявності у них супутнього ХП. 


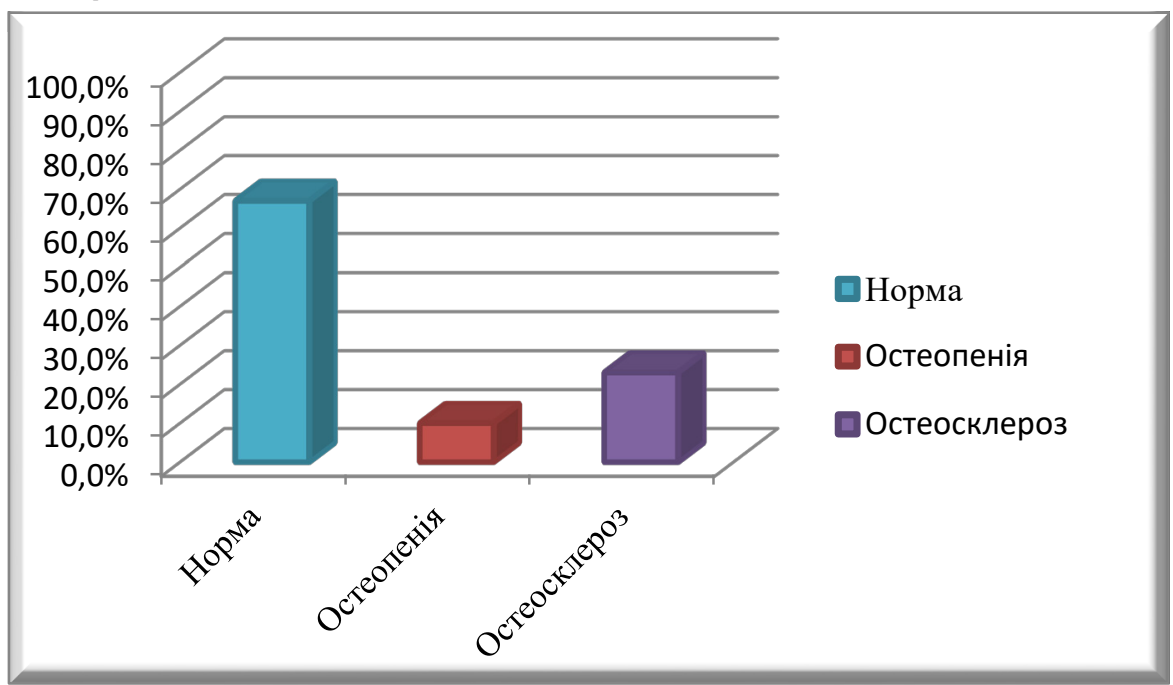

Рис. 1. Стан мінеральної щільності кісткової тканини хворих на остеоартроз.

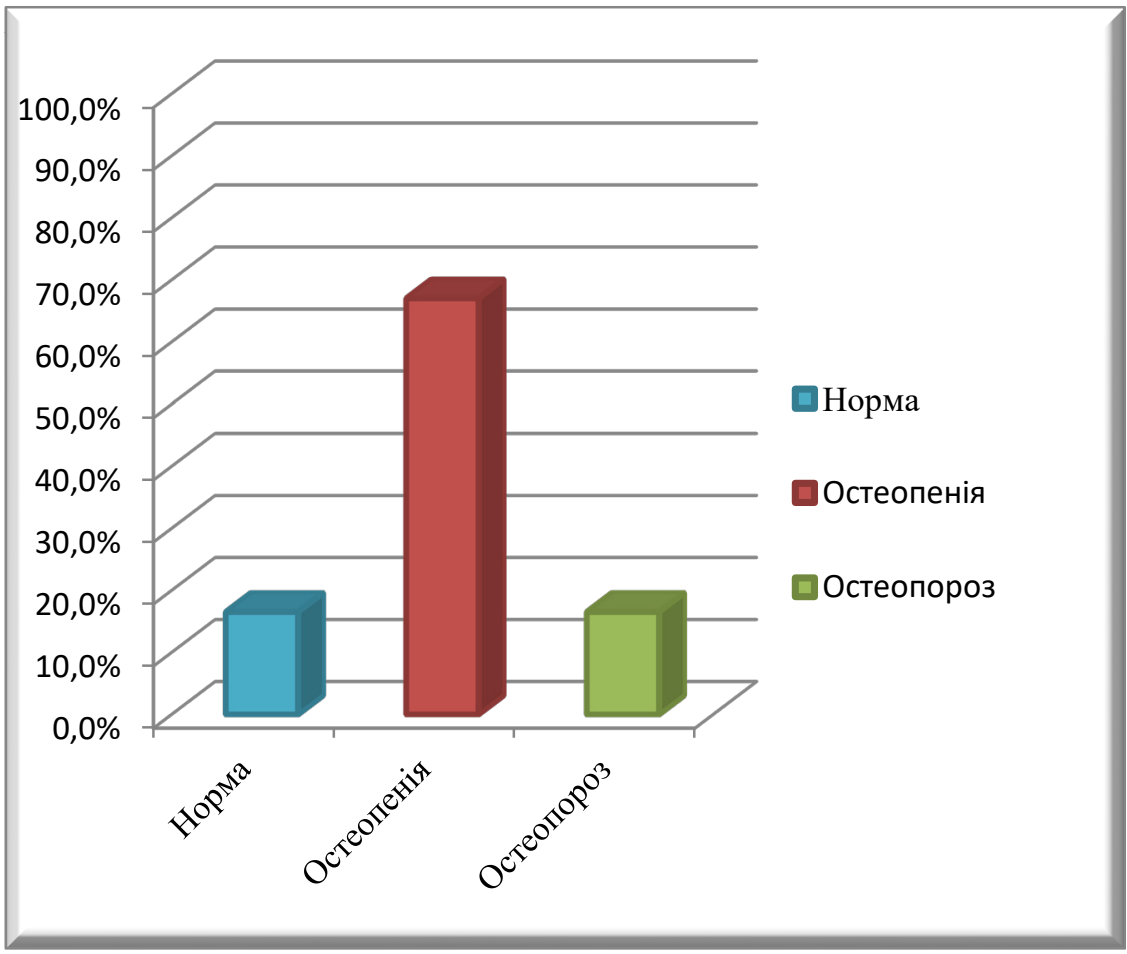

Рис. 2. Стан мінеральної щільності кісткової тканини хворих на остеоартроз та хронічний панкреатит.

У групі хворих на ОА+ХП було констатовано достовірно вищий рівень посилення ПОЛ за показником МА (на 5,42 \%) і зниження $\mathrm{AO}$ за рівнем SH-груп, СОД (на 4,31\%), підвищення активності церулоплазміну та каталази (12,77\%), а також збільшення рівня маркера деструкції сполучної тканини і ендотоксикозу - оксипроліну - у порівнянні з аналогічними показниками пацієнтів з ОА. Збільшення деградації КТ при ОА на тлі ХП супроводжувалось посиленням оксидативних змін (за рівнем МА), ослабленням АОЗ (за рівнем СОД і SH-груп), збільшенням гостроти запалення та ендотоксикозу (за рівнем каталази, церулоплазміну), а також посиленням деградації сполучної і кісткової тканин у суглобах і прогресуванням фіброзу у тканині ПЗ (за рівнем оксипроліну).

У ході дослідження було проаналізовано взаємозв'язки між основними параметрами ХП (вік пацієнтів, тривалість коморбідного перебігу ХП і ОА, рівень фекальної а-еластази, структурний стан ПЗ за УЗ-критеріями у балах) і МЩКТ (за денситометричним показником Т\%) та показниками стану ПОЛ-АОЗ у хворих із поєднаним перебігом ОА і ХП на тлі остеопенії. У таблиці 2 наведені дані кореляційно-ре- 
Огляди літератури, оригінальні дослідження, погляд на проблему

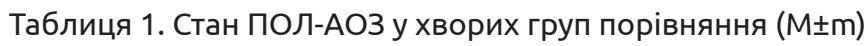

\begin{tabular}{|c|c|c|c|}
\hline \multirow{2}{*}{$\begin{array}{l}\text { Показник } \\
\text { ПОЛ-АОЗ }\end{array}$} & \multicolumn{3}{|c|}{ Група порівняння } \\
\hline & $\begin{array}{c}\text { контрольна група } \\
(n=20)\end{array}$ & $\begin{array}{c}\text { I група (OA) } \\
(n=30)\end{array}$ & $\begin{array}{c}\text { II група (OA+XП) } \\
(n=42)\end{array}$ \\
\hline $\begin{array}{l}\text { МА, } \\
\text { ммоль/л }\end{array}$ & $2,86 \pm 0,01$ & $\begin{array}{r}6,27 \pm 0,11 \\
(p<0,05)^{*}\end{array}$ & $\begin{array}{r}6,61 \pm 0,14 \\
(p<0,01)^{*}\end{array}$ \\
\hline $\begin{array}{l}\text { SH-групи, } \\
\text { ммоль/л }\end{array}$ & $61,57 \pm 0,17$ & $\begin{array}{c}38,80 \pm 0,64 \\
(p<0,001)^{*}\end{array}$ & $\begin{array}{c}36,27 \pm 0,60 \\
(p<0,01)^{*} \\
(p<0,05) * *\end{array}$ \\
\hline СОД, ум.од. & $63,57 \pm 0,91$ & $\begin{array}{l}40,29 \pm 0,60 \\
(p<0,001)^{*}\end{array}$ & $\begin{array}{c}38,55 \pm 0,70 \\
(p<0,01)^{*}\end{array}$ \\
\hline Каталаза, \% & $15,48 \pm 0,06$ & $\begin{array}{r}55,12 \pm 0,99 \\
(p<0,01) *\end{array}$ & $\begin{array}{c}62,16 \pm 0,98 \\
(p<0,01)^{*} \\
(p<0,001)^{* *}\end{array}$ \\
\hline $\begin{array}{l}\text { Церулоплазмін, } \\
\text { мг/л }\end{array}$ & $243,60 \pm 2,73$ & $\begin{array}{r}617,66 \pm 12,09 \\
(p<0,05)^{*}\end{array}$ & $\begin{array}{c}631,14 \pm 11,12 \\
(p<0,01)^{*}\end{array}$ \\
\hline Оксипролін, мкмоль/л & $30,89 \pm 0,17$ & $\begin{array}{c}76,57 \pm 2,11 \\
(p<0,001)^{*}\end{array}$ & $\begin{array}{c}89,85 \pm 2,25 \\
(p<0,05)^{*} \\
(p<0,001)^{* *}\end{array}$ \\
\hline
\end{tabular}

Примітки: 1.* - вірогідна відмінність стосовно групи контролю;

2.** - вірогідна відмінність стосовно хворих на ОА.

Таблиця 2. Кореляційні зв'язки між показниками ПОЛ-АОЗ у хворих на ОА+ХП і основними характеристиками ХП і МЩКТ

\begin{tabular}{|l|c|c|c|c|c|}
\hline $\begin{array}{c}\text { Пари в регресійному } \\
\text { зв'язку }\end{array}$ & $\begin{array}{c}\text { Вік хворого, } \\
\text { роки }\end{array}$ & $\begin{array}{c}\text { Тривалість } \\
\text { перебігу ОА+ХП, } \\
\text { роки }\end{array}$ & $\begin{array}{c}\text { Рівень } \\
\text { a-еластази, } \\
\text { мкг/г }\end{array}$ & узд, бали & Т(\%) \\
\hline Оксипролін, мкмоль/л & 0,454 & 0,448 & $-0,479$ & $-0,495$ & $-0,342$ \\
& $\mathrm{n}=28$ & $\mathrm{n}=28$ & $\mathrm{n}=28$ & $\mathrm{n}=28$ \\
$\mathrm{p}<0,01$ & $\mathrm{p}<0,01$ & $\mathrm{p}<0,01$ & 01 & $\mathrm{p}<0,01$ \\
\hline МА, ммоль/л & 0,403 & 0,457 & $-0,348$ & 0,342 & $-0,368$ \\
& $\mathrm{n}=28$ & $\mathrm{n}=28$ & $\mathrm{n}=28$ & $\mathrm{n}=28$ & $\mathrm{n}=28$ \\
& $\mathrm{p}<0,001$ & $\mathrm{p}<0,01$ & $\mathrm{p}<0,05$ & $-0,05$ & $\mathrm{p}<0,01$ \\
\hline СН-групи, ммоль/л & 0,385 & $-0,289$ & 0,281 & $-0,310$ \\
& $\mathrm{n}=28$ & $\mathrm{n}=28$ & $\mathrm{n}=28$ & $\mathrm{n}=28$ & $\mathrm{n}=28$ \\
& & & $\mathrm{p}<0,05$ & $\mathrm{p}<0,01$ \\
\hline СОД, ум. од. & $-0,428$ & $-0,395$ & 0,321 & 0,366 \\
& $\mathrm{n}=28$ & $\mathrm{n}=28$ & $\mathrm{n}=28$ & $\mathrm{n}=28$ & $\mathrm{n}=28$ \\
& $\mathrm{p}<0,01$ & $\mathrm{p}<0,01$ & $\mathrm{p}<0,05$ & $\mathrm{p}<0,05$ & $\mathrm{p}<0,01$ \\
\hline Каталаза, \% & $-0,483$ & 0,424 & $-0,373$ & $-0,393$ & $-0,369$ \\
& $\mathrm{n}=28$ & $\mathrm{n}=28$ & $\mathrm{n}=28$ & $\mathrm{n}=28$ & $\mathrm{n}=28$ \\
& $\mathrm{p}<0,05$ & $\mathrm{p}<0,05$ & $\mathrm{p}<0,05$ & $\mathrm{p}<0,05$ & $\mathrm{p}<0,05$ \\
\hline Церулоплазмін, мг/л & 0,302 & 0,439 & $-0,522$ & 0,358 & $-0,459$ \\
& $\mathrm{n}=28$ & $\mathrm{n}=28$ & $\mathrm{n}=28$ & $\mathrm{n}=28$ & $\mathrm{n}=28$ \\
& $\mathrm{p}<0,01$ & $\mathrm{p}<0,05$ & $\mathrm{p}<0,05$ & $\mathrm{p}<0,05$ & $\mathrm{p}<0,05$ \\
\hline
\end{tabular}

Примітки: $\mathrm{n}$ - кількість пар в кореляційному аналізі; p - ступінь достовірності кореляційної залежності.

гресійного аналізу між наведеними вище показниками.

Виявлено, що із збільшенням віку хворих, тривалості перебігу поєднаних захворювань - ОА і ХП, параметра УЗД-балів ПЗ, а також із зниженням рівня а-еластази і ступеня МЩКТ відбувалося накопичення в сироватці крові оксипроліну, про що свідчать середньої сили кореляційні зв'язки між цими параметрами, що констатує наявність прогресування деструкції кістки і хряща, а також тканин ПЗ у хворих 3 поєднаним перебігом ОА+ХП на тлі остеопенії.

Висновки. 1. Наявність у хворих на ОА супутнього ХП призводить до суттєвого зниження МЩКТ і погіршення стану КТ: знизилась частка 
Огляди літератури, оригінальні дослідження, погляд на проблему

хворих з нормальною кісткою з 67 \% до 16 \%, збільшилась - з остеопенією з 10 \% до 67\%, з'явились хворі з ОП - 17 \%.

2. Деградація кістки при ОА на тлі ХП супроводжувалась посиленням оксидативних змін (за рівнем МА), ослабленням АОЗ (за рівнями СОД і SH-груп), збільшенням гостроти запалення та ендотоксикозу (за рівнем каталази, церулоплазміну), а також посиленням деградації сполучної і кісткової тканин у суглобах і прогресуванням фіброзу у тканині ПЗ (за рівнем оксипроліну).

3. Із збільшенням віку хворих, тривалості перебігу поєднаних захворювань - ОА і ХП, параме- тра УЗД-балів П3, а також із зниженням рівня а-еластази і ступеня МЩКТ відбувалося накопичення в сироватці крові оксипроліну (встановлено середньої сили кореляційні зв'язки між цими параметрами), що свідчить про наявність прогресування деструкції кістки і хряща, а також тканин ПЗ у хворих з поєднаним перебігом ОА+ХП на тлі остеопенії.

Перспективи подальших досліджень. У подальшому планується поглибити вивчення клініко-патогенетичних особливостей поєднаного перебігу остеоартрозу, хронічного панкреатиту і остеодефіцитів.

\section{ЛІТЕРАТУРА}

1. Алексеева Л. И. Остеоартроз и остеопороз : руководство по остеопорозу / Л. И. Алексеева ; под ред. Л. И. Беневоленской. - М. : Бином, 2003. - 503 с.

2. Бабінець Л. С. Взаємозв'язок стану кісткової тканини, параметрів анемії та білкового статусу при хронічному панкреатиті / Л. С. Бабінець // Український морфологічний альманах. - 2008 - Т. 6, № 3 - С. 93-95.

3. Верткин А. Л. Деформирующий остеоартроз: стратегия ведения пациентов при соматической патологии / А. Л. Верткин, А. В. Наумов // Рос. мед. журн. -2007.

4. Гайдаєв Ю. А. Стан здоров'я населення України та забезпечення надання медичної допомоги : аналітично-статистичний посібник / Ю. А. ГайдаєВ, В. М. Ковалєнко, В. М. Корнацький - Київ, 2012. - 97 с.

5. Гайко Г. В. Особливості патоморфологічних змін головки стегнової кістки у хворих на остеоартроз кульшового суглоба / Г. В. Гайко, А. Т. Бруско, О. В. Калашніков // Боль. Суставы. Позвоночник. - 2014. - № 1/2. - С. 9-13.

6. Казимирко В. К. Инволюционный остеоартроз и остеопороз / В. К. Казимирко, В. Н. Коваленко, В. В. Флегонтова. - Донецк, 2011. - 721 с.

7. Коваленко В. Н. Остеопороз : практическое руководство / В. Н. Коваленко, О. П. Борткевич. - К. : Морион, 2003. -448 с.

8. Лазебник Л. Д. Заболевания органов пищеварения у пожилых / Л. Д. Лазебник, В. Н. Дроздов. М. : Анахарсис, 2003. - 208 с.

9. Насонова В. А. Остеоартроз - проблема полиморбидности / В. А. Насонова // Український медичний часопис. - 2009. - № 6. - С. 81-84.

10. Уніфікований клінічний протокол первинної, вторинної (спеціалізованої) медичної допомоги та медичної реабілітації / Міністерство охорони здоров'я україни 10.09.2014, № 638.

11. Ураження шлунково-кишкового тракту при остеоартрозі / Л. А. Ткаченко, І. П. Катеренчук, Т. І. Ярмо- ла, А. Л. Пустовойт // Світ медицини та біології. - 2010. - № 2. - С. 183-1862.

12. Пасієшвілі Л. М. Порушення кальцієвого обміну як предиктор формування вторинного остеопорозу у хворих на хронічний панкреатит. Патогенетичні аспекти взаємозв'язку та взаємообтяження / Л. М. Пасієшвілі, Л. М. Бобров, М. В. Моргуліс // Сучасна гастроентерологія. - 2008. - № 3 (41). - С. 4-8.

13. Сметник В. П. Проблема остеопороза: новые терапевтические решения и долговременная клиническая эффективность / В. П. Сметник // Consilium Medicum. - 2010. - № 6. - C. 13-16.

14. Сучасні класифікації та стандарти лікування розповсюджених захворювань внутрішніх органів / за ред. Мостового Ю. М. - 14-те вид., доп. і переро6. - Вінниця, 2012. -576 с.

15. Subchondral bone as a key target for osteoarthritis treatment / S. Castaneda, J. A. Roman-Blas, R. Largo [et al.] // Biochem. Pharmacol. - 2012. - № 83. - P. 315-323.

16. EULAR recommendations for the nonpharmacological core management of hip and knee osteoarthritis / L. Fernandes, H. Lund, C. D. Mallen [et al.] // Ann. Rheum. Dis.-DOI: 10.1136/annrheumdis-2012-202745.

17. Hochberg M. Osteoarthritis year 2012 in review: clinical / M. Hochberg // Osteoarthritis Cartilage. - 2012. № 20. - P. 1465-1469.

18. Neogi T. Clinical significance of bone changes in osteoarthritis / T. Neogi // Ther. Adv. Musculoskelet. Dis. 2012. - № 4. - P. 259-267.

19. World Health Organization:Assessement of fracture risk and its application to screening for postmenopausal osteoporosis. WHO Technical Report Series 843. - WHO, Geneva, 1994.

20. Quality of life and functional outcome at 3,6 and 12 months after acute necrotising pancreatitis / S. E. Wright, R. Lochan, K. Imrie [et al.] // Intensive Care Med. - 2009. - № 8. - P. 37-44.

\section{REFERENCES}

1. Alieksieiva, L.I. (2003). Osteoartroz i osteoporoz: [Osteoarthritis and osteoporosis]. Rukovodstvo po osteoporozu. L.I. Benevolencka (Ed.). Moscow: Binom [in Russian].
2. Babinets, L.S. (2008). Vzaiemozviazok stanu kistkovoi tkanyny, parametriv anemii ta bilkovoho statusu pry khronichnomu pankreatyti [The relationship between bone 
Огляди літератури, оригінальні дослідження, погляд на проблему

condition and parameters of anemia and protein status in chronic pancreatitis]. Ukrainskyi morfolohichnyi almanakh Ukrainian Morphological Almanac, 3, 93-95 [in Ukrainian].

3. Vertkyn, A.L., \& Naumov, A.V., (2007). Deformuiuchyi osteoartroz: stratehiia vedennia patsiientiv pry somatychnii patolohii. [Deforming osteoarthritis: a strategy for the management of patients with somatic pathology]. Rosiiskyi medychnyi zhurnal - Russian Medical Journal [in Russian].

4. Haidaiev, Yu.A., Kovalenko, V.M., \& Kornatskyi,V.M., (2014). Stan zdorovia naselennia Ukrainy ta zabezpechennia nadannia medychnoi dopomohy. Analitychno-statystychnyi posibnyk [The state of health of the Ukrainian population and providing the medical assistance. Analytically-statistical handbook]. Kyiv [in Ukrainian].

5. Haiko, H.V., Brusko, A.T., \& Kalashnikov, O.V., (2014). Osoblyvosti patomorfolohichnykh zmin holovky stehnovoi kistky u khvorykh na osteoartroz kulshovoho suhloba [Features of pathological changes of the femoral head in patients with osteoarthritis of the hip joint]. Bil. Suglloby. Chrebet - Pain. Joints. Spine, 1 (2), 9-13 [in Ukrainian].

6. Kazemirko, V.K., Kovalenko, O.P., \& Flegontova, V.V., (2011). Involiutsiinyi osteoartroz i osteoporoz [Involutional osteoarthritis and osteoporosis]. Donetsk [in Ukrainian].

7. Kovalenko, V.N., \& Bortkevych, O.P., (2003). Osteoporoz. Praktychnyi posibnyk [Osteoporosis. A practical guide]. Kyiv: Morion [in Ukrainian].

8. Lazebnik, L.D., \& Drozdov, V.N., (2003). Zabolevaniya organov pishchevareniya u pozhelykh [Diseases of the digestive system in the elderly]. Moscow: Anacharsis [in Russian].

9. Nasonov, V.I., (2009). Osteoartroz - problema polimorbidnosti [Osteoarthritis - a problem of polymorbidity]. Ukrainskyi medychnyi chasopys - Ukrainian Medical Journal, 6, 81-84 [in Ukrainian].

10. Unifikovanyi klinichnyi protokol pervynnoi, vtorynnoi (spetsializovanoi) medychnoi dopomohy ta medychnoi reabilitatsii [Unified clinical Protocol of primary, secondary (specialized) medical care and rehabilitation] Ministerstvo okhorony zdorovia Ukrainy - The Ministry of Health of Ukraine [in Ukrainian].
11. Tkachenko, L.A., Katerenchuk, I.P., Yarmola, T.I., Pustovoit, A.L., \& Yermalynskyi, F.A. (2010). Urazhennia shlunkovo-kyshkovoho traktu pry osteoartrosi [Lesions of the gastrointestinal tract in osteoarthritis]. Svit medytsyny ta biolohiiThe world of Medicine and Biology, 2, 183-186 [in Ukrainian].

12. Pasiieshvili, L.M., Bobrov, L.M., \& Morgulis, M.V., (2008). Poryshennia kaltsiievogo obminu iak predyktor formuvannia vtorynnoho osteoporozu u khvorykh na khronichnyi pankreatyt [Violation of calcium metabolism as a predictor of the formation of secondary osteoporosis in patients with chronic pancreatitis.]. Suchasna hastroenterolohiia - Modern Gastroenterology, 3 (41), 4-8 [in Ukrainian].

13. Smetnyk, V.P. (2010). Problema osteoporoza: novye terapevticheskie resheniia i dolgovremennaia klinicheskaia efektivnost [The problem of osteoporosis: new therapeutic solutions and long-term clinical efficacy]. Konsilium medikum - Consilium Medicum, 6, 13-16 [in Russian].

14. Mostovyi, Yu.M., (2012). Suchasni klasyfikatsii ta standarty likuvannia rozpovsiudzhenykh zakhvoriuvan vnutrishnikh orhaniv [Modern classification and treatment of common diseases of internal organs]. Vinnytsia: DP «DKF» [in Ukrainian].

15. Castaneda, S., Roman-Blas, J.A., Largo, R. (2012). Subchondral bone as a key target for osteoarthritis treatment. Biochem. Pharmacol., 315-323.

16. Fernandes, L., Lund, H., Mallen, C.D. (2012). EULAR recommendations for the non-pharmacological core management of hip and knee osteoarthritis. Ann. Rheum. Dis. doi: 10.1136/annrheumdis-2012-202745.

17. Hochberg, M. (2012). Osteoarthritis year 2012 in review: clinical. Osteoarthritis Cartilage, 20, 1465-1469.

18. Neogi, T. (2012). Clinical significance of bone changes in osteoarthritis. Ther. Adv. Musculoskelet. Dis., 4, 259-267.

19. World Health Organization:Assessement of fracture risk and its application to screening for postmenopausal osteoporosis. WHO Technical Report Series 843. WHO, Geneva,1994.

20. Wright, S.E., Lochan, R., Imrie, K., Baker, C., Nesbitt, I.D., Kilner, A.J. (2009). Quality of life and functional outcome at 3, 6 and 12 months after acute necrotising pancreatitis. Intensive Care Med., 8, 37-44.

\title{
КЛИНИКО-ПАТОГЕНЕТИЧЕСКИЕ АСПЕКТЫ ОСТЕОДЕФИЦИТА ПРИ ОСТЕОАРТРОЗЕ В СОЧЕТАНИИ С ХРОНИЧЕСКИМ ПАНКРЕАТИТОМ
}

ФЛ. С. Бабинец, Т. Г. Маевская

\author{
гвуз «Тернопольский государственный медицинский университет имени И. Я. Горбачевского \\ МОЗ Украины»
}

РЕЗЮМЕ. В статье рассмотрены современные взгляды на проблему коморбидности остеоартроза, хронического панкреатита и остеодефицита. Проанализированы данные двухфотонной рентгеновской денситометрии, а также показатели уровня активации перекисного окисления липидов, антиоксидантной системы защиты и деструкции ткани. Продемонстрированы данные корреляционно-регрессионного анализа между приведенными выше показателями и основными характеристиками хронического панкреатита и остеодефицита у больных рассматриваемого контингента.

Материалы и методы. Проведено комплексное обследование 72 больных. Пациенты были разделены на две группы: 30 больных ОА и 42 - ОА в сочетании с ХП. Контрольная группа состояла из 20 практически здоровых лиц. Оценку КТ проводили с помощью двухфотонного рентгеновского денситометра (Dual Energy X-Ray Absorptiometry DXA) фирмы Lunar corp. (Madison, WI) - Lunar DPX-A № 2589 в поясничном отделе позвоночника. Анализ проводили 
Огляди літератури, оригінальні дослідження, погляд на проблему

согласно рекомендациям Всемирной Организации здравоохранения (WHO, Geneva, 1994) [19]. Исследование показателей ПОЛ проводили по уровню малонового альдегида (MA). Для оценки АОЗ определяли СОД, церулоплазмин (ЦП), SH-группы, каталазу. Эндогенную интоксикацию и уровень деградации соединительной ткани в организме оценивали по уровню свободного оксипролина. Влияние наличия ХП на состояние ПОЛ-АОЗ устанавливали по следующим основным клиническим характеристикам ХП: возраст пациентов, структурное состояние ПО по методу УзИ, выраженное в баллах. Экскреторную функцию ПО исследовали с помощью определения фекальной а-эластазы методом иммуноферментного анализа с помощью стандартных наборов фирмы BIOSERV ELASTASE 1-ELISA.

Результаты. При обследовании минеральной плотности костной ткани с помощью двухфотонного рентгеновского денситометра было выяснено, что наличие у больных ОА сопутствующего ХП привела к существенному снижению МПКТ и ухудшению состояния КТ: снизилось количество больных с нормальной костью с $67 \%$ до $16 \%$, увеличилось - с остеопенией с 10 \% до 67 \%, появились больные с ОП - 17 \%. Кроме усиления деградации КТ при ОА на фоне ХП усиливались показатели оксидативных изменений (уровень МА) и снижались показатели AO3 (уровень СОД и SH-групп), характерными были увеличение остроты воспаления и эндотоксикоза (уровень каталазы, церулоплазмина), а также усиление деградации соединительной и костной ткани в суставах и прогрессирование фиброза в ткани ПО (уровень оксипролина).

Выводы. Доказано, что у больных ОА с сопутствующим ХП наблюдалось существенное снижение МПКТ и ухудшение состояния КТ. Обнаружено, что при совместном протекании ОА+ХП с остеопенией наблюдается снижение АОЗ по уровню СОД и SН-групп и достоверно более высокий уровень активации ПОЛ по данным МА, а также наличие деструктивных изменений в соединительной и костной ткани и усиление остеопении, на что указывает рост оксипролина.

КЛЮЧЕВЫЕ СЛОВА: остеоартроз, остеопения, остеопороз, хронический панкреатит, антиоксидантная защита, перекисное окисление липидов, оксипролин.

\section{CLINICO-PATHOGENICAL ASPECTS OF OSTEODEFICIENCY AT OSTEOARTHRITIS IN COMBINATION WITH CHRONIC PANCREATITIS}

\section{Horbachevsky Ternopil State Medical University}

SUMMARY. The article deals with modern views on the problem of comorbidity of osteoarthritis, chronic pancreatitis and osteodeficiency. Dual energy X-ray densitometry data were analyzed, as well as indicators of activation of lipid peroxidation (malonic aldehyde), antioxidant protection system (superoxide dismutase and SH-group, ceruloplasmin, catalase) and tissue destruction (oxyproline). The data of correlation and regression analysis between the above mentioned indicators and the main features of chronic pancreatitis and osteodeficiency in patients of the analyzed contingent were demonstrated.

Materials and Methods. The complex examination of 72 patients was made. Patients were divided into two groups: 30 patients with OA and 42 - with OA in combination with CP. The control group included 20 apparently healthy individuals. Evaluation of CT scan was performed using Dual Energy X-Ray Absorptiometry - DXA by Lunar corp. (Madison, WI) - Lunar DPX-A No. 2589 in the lumbar region of the vertebral column. The evaluation of the indicators was carried out in accordance with WHO recommendations (WHO, Geneva, 1994) [19]. The study of LPO was carried out on the level of malonic aldehyde (MA). To assess AOP, we determined SOD, ceruloplasmin (CPN); SH-groups; catalase. The endogenous intoxication and the level of degradation of the connective tissue in the body was estimated by levels of free oxyproline. The influence of CP on the state of LPO-AOP was established by the following clinical characteristics of CP: age of the patients, structural condition of the pancreas with the help of the method of ultrasound, expressed in points. Excretory function of the pancreas was investigated on the level of fecal a-elastase ( by ELISA test using the kits BIOSERV ELASTASE 1-ELISA).

Results. During the examination of the mineral bone density by the dual energy X-ray densitometry it was discovered that the presence of CP in patients with OA led to a significant reduction of BMD and deterioration of the bone tissue (BT): the proportion of patients with normal bone decreased from $67 \%$ to $16 \%$, the number of patients with osteopenia increased from $10 \%$ to $67 \%$; patients with OP appeared - 17\%.Besides, the increased degradation of bone tissue in OA with CP was accompanied by strengthening of oxidative changes (by MA-level), weakening of the antioxidant defense (SOD and SH-groups), the increase in the severity of inflammation and endotoxemia (levels of catalase and ceruloplasmin), as well as increased degradation of connective and bone tissue in the joints and progression of fibrosis in tissue (the level of oxyproline).

Conclusions. It was found out that the presence of CP in patients with OA led to a significant reduction of BMD and the deterioration of the bone tissue. It was discovered that during the combined course of OA and CP with osteopenia there occurs the weakening of the AOP (by SOD and SH-groups) and a relatively high level of LPO activation (by MA-level) as well as the increased deterioration in connective and bone tissue and aggravation of osteopenia which is indicated by the increased levels of oxyproline.

KEY WORDS: osteoarthritis; osteopenia; osteoporosis; chronic pancreatitis; antioxidant protection; lipid peroxidation; oxyproline. 